\title{
Siedemnastowieczna polszczyzna kijowska w panegirykach Stefana Jaworskiego
}

\author{
$17^{\text {th }}$-century Kiyvan Polish in Stefan Jaworski's Panegyrics
}

Słowa klucze: polszczyzna regionalna, fleksja, fonetyka, historia języka polskiego Key words: dialects of Polish, inflection, phonetics, history of the Polish language

Aleksander Brückner pisał:

Już w XV wieku zaczynał Rusin zaspokajać głód duchowy u źródeł polskich: nie zważając na różnice wyznaniowe, na dogmaty przeciwne, tłumaczył sobie pisma budujące polskie, a za nimi w końcu i wcale niebudujące, na język własny. Zachowując język i pismo ruskie, pstrzył je przymieszkami polskiemi; [...] tekst bywa ruski, bo formy i litery ruskie, ale myśl i wysłowienie są polskie; polszczyzna-to pod zewnętrzną, narzuconą szatą ruską, co do ducha, treści, stylu, formy. Niedokształcenie ruskie ustępywało powoli wykształceniu polskiemu, znienawidzonej łacinie, wzorom jezuickim.

BRÜCKNER, 1918: 160

Opinia ta jest prawdziwa nie tylko w odniesieniu do XV wieku, gdyż „przymieszki polskie” $w$ tekstach powstających we wschodniej części Rzeczypospolitej Obojga Narodów nie zanikły aż do końca XVII wieku. Nierzadko nawet ich proporcje ulegały odwróceniu, tak że spod pióra Rusinów wychodziły teksty pisane po polsku z „przymieszką ruską” (niekiedy sporadyczną; por. Brogi Bercoff, 2014: 332).

Jednym z takich pisarzy był Stefan Jaworski'. Urodził się w 1656 lub w 1658 roku w Jaworowie (dziś, dawniej Jawor), miasteczku nieopodal Lwowa, w prawosławnej, niezbyt zamożnej rodzinie szlacheckiej herbu Sas (polskiej lub ukraińskiej, źródła nie podają jednoznacznej informacji). Jeszcze jako dziecko wraz z rodzicami - według źródeł rosyjskich - schronił się przed prześladowaniem ze strony unitów w Nieżynie (Ukraina północna, obwód czernihowski). Po ukończeniu kolegium kijowsko-mohylańskiego, chcąc kształcić

* e-mail: jolanta.klimek@kul.pl

1 Biografia na podstawie materiałów ze stron: Ortho-rus [online: http://www.ortho-rus.ru/cgi -bin/ps_file.cgi?2_4433], William Shakespeare [online: http://william-shakespeare.gq/Stefan_Yauorsky], Chronos [online: http://www.hrono.ru/biograf/bio_ya/jauorski_s.php]. 
się dalej, przeszedł na katolicyzm i studiował filozofię oraz teologię w kolegiach jezuickich we Lwowie, w Lublinie, Poznaniu i Wilnie. Wówczas też zaczął pisać wiersze po polsku, łacinie i cerkiewnosłowiańsku - tymi językami, jak podaje Władysław GuLEwicz ([online]), Jaworski władał znakomicie. W 1687 lub 1689 roku Stanisław Symeon (takie imię przyjął po konwersji) wrócił do Kijowa, rekonwertował na prawosławie i za namową Warłama Jasińskiego złożył śluby zakonne i zasilił ławrę peczerską. W 1690 roku został wykładowcą Akademii Kijowsko-Mohylańskiej, rok później jej prefektem, a w 1697 roku igumenem ławry. Cerkiewna kariera Stefana nabrała tempa w styczniu 1700 roku, gdy Piotr I, pod wrażeniem kazania wygłoszonego na pogrzebie wojewody moskiewskiego Szeina, nakazał Adrianowi (patriarsze Moskwy) wyświęcić igumena na biskupa i osadzić na którejś eparchii niedaleko Moskwy. Opór Stefana na nic się nie zdał - w kwietniu został biskupem riazańsko-muromskim i otrzymał godność metropolity. Po śmierci patriarchy Adriana mianowano go locum tenens patriarchatu moskiewskiego i - mimo próśb o zwolnienie go z tej funkcji - do końca życia pozostał marionetkowym administratorem, a po powołaniu przez cara Świątobliwego Synodu Rządzącego w 1721 roku - jego przewodniczącym nieuczestniczącym w obradach. Polecenia cara wykonywał nawet z Petersburga, dokąd udał się na rozkaz - de facto zesłanie - Piotra I. Zmarł w Moskwie w 1722 roku.

Przedmiotem opracowania jest wyznaczona tytułem analiza historycznej polszczyzny kijowskiej w polsko-łacińskich panegirykach na cześć Warłama Jasińskiego: Arctos caeli Rossiaci... (1690) i Pełnia riężyca $w$ kleynocie swiecącego... (1691) wydanych przez działający od 1633 roku polski dział drukarni ławry kijowskiej. Moim celem jest nie tylko pełniejsze udokumentowanie stanu języka polskiego w siedemnastowiecznym Kijowie, który w czasie, gdy powstały teksty, pozostawał już pod zwierzchnością moskiewską, lecz także ustalenie cech specyficznych dla tej regionalnej odmiany polszczyzny².

$\mathrm{Na}$ polską część poddawanych analizie tekstów źródłowych składają się:

1) w Arctos caeli... - pięć tekstów wierszowanych (cztery tytułowane: Arctos herbowych planet, ktora nie tylko rosski horyzont oswieca..., Arctos herbowych planet, do ktorey swoy bieg rossyiska konformuiąc nawa..., Arctos planet herbowych, na ktorey niebopodobna szkoł kiiowskich sphera..., Arctos herbowych planet, ktora lub wszytkich planet mnostwo $w$ zachod godzi..., i jeden bez tytułu) oraz cztery prozatorskie; w sumie 18 stron druku. Cztery pierwsze wiersze (tytułowane) konsekwentnie pisane są akrostychem nieparzyste wersy układają się $w$ imię i nazwisko adresata panegiryku: BARLAAM IASINSKI METROPolita KIIOWSKı halickı. Dopełnieniem ostatniego Arctos... jest czterowiersz zawierający podpis autora:

Szczupłe To moiey uprzEymości myto,

Przyiąć cHetnie rAcz cNy metropolito

pIoro zAś gorney niesWiadOme dRogi

za Swe defeKta lecl pod twe nogi.

${ }^{2}$ Na temat dialektalnej przynależności historycznej polszczyzny kijowskiej pisałam we wcześniejszym artykule: Кьімек, 2010. 
2) w Pełni riężyca... - dedykacja dla Warłama Jasińskiego, trzy teksty wierszowane (Divo Barlaamo Anachoretae, Divo Barlaamo Martyri i Mnemosine...) i jeden prozatorski, co $w$ sumie daje 33 strony druku. Cechą łączącą partie wierszowane jest rymowanie parzyste lub krzyżowe (tylko w drugiej części Mnemosine).

Tak zróżnicowana rodzajowo podstawa źródłowa pozwala nie tylko na wnioskowanie wprost o nienacechowanym stylistycznie systemie językowym poety, ale i o sposobach artystycznego wyzyskania potencjału nieustabilizowanej jeszcze fleksyjnie i wykazującej fonetyczne zróżnicowanie regionalne kijowskiej polszczyzny końca XVII wieku.

Obserwacja wiersza Jaworskiego pod kątem rymów pozwala stwierdzić dużą sprawność poety w tym zakresie, gdyż wyraźnie dominują rymy niegramatyczne. Współbrzmieniem objęte są dwie części mowy, na przykład: kupcowi : mowi, trzeba : Nieba, Wieszczkowie : powie, oblecze : człowiecze, opoko : głęboko, sieci : wyleci, cudnie : Południe, roży : sroży, płochy : lochy, lub tożsame części mowy zróżnicowane kategorialnie, między innymi: włosienica : Krolewica, karze : Luminarze, klarze : Marynarze, chmury : Cynozury, Karete : Waletę, stopy : Pyropy, wiry : Zefiry, siły : Mohiły, porze : zorze. Taka praktyka z jednej strony wpływa na artyzm tekstu i potwierdza biegłość poety, z drugiej zaś jest swoistym świadectwem kompetencji językowych autora. Niech to stanowi punkt wyjścia do rozważań o jakości jego polszczyzny i jej powinowactwie z innymi odmianami regionalnymi (zwłaszcza mającymi już bogatą literaturę przedmiotu odmianami południowo- i północnokresową) oraz polszczyzną ogólną XVII wieku.

Operowanie rozmaitymi elementami językowymi sytuującymi się na pograniczu - wciąż de facto płynnej w XVII wieku - normy systemu gramatycznego lub wręcz poza nią w przywoływanych panegirykach Stefana Jaworskiego zaobserwować można w każdej - nacechowanej i nienacechowanej partii tekstu poetyckiego, jak również $w$ partiach prozatorskich Pełni xiężyca..., co nie pozostaje bez znaczenia.

W zakresie ortografii uwagę zwraca oddawanie ubezdźwięczniania spółgłosek (w wygłosie lub przed bezdźwięczną): bespiecznym, niebespiecznym, prętko, prętki, roskaz, Narcys, i niemal bezwyjątkowo $w$ prefiksie roz-: roskwitłych, rospłynąt, rospłynąć, rosproszonych, roskwilonych. Nie ma tu znaczenia troska o dokładność rymu - zaburzenia ortografii zdarzają się wręcz częściej $w$ nienacechowanych niż $w$ nacechowanych miejscach wierszy Jaworskiego, w przypadku prefiksu niemożliwe zaś jest, aby w grę wchodziła akomodacja stylistyczna. Fonetyka ta $w$ pełni zbieżna jest z poświadczoną w źródłach pochodzących z różnych regionów Polski (Sıcı́́sKA, 2013: 178-179).

Podobnie częste zjawisko stanowi mieszanie $u$ i $w$ w obcej grupie au, eu: Lawrem, klawzurze (: naturze), aplawzem, aplawz, Mawrytanskich, Kawkaz, Awster, Kawkazowey, restawruie, klawzury (: pazury), Jozwego. Tu również nie ma znaczenia miejsce, w jakim znajduje się wyraz - w rymie czy poza nim. Analogicznych przykładów z Kresów północnych dostarczają badania między innymi Alicji PınAn-KıJAsowej (1999: 172), z Kresów południowych zaś - Katarzyny SicıŃSKIEJ (2013: 175).

Warte odnotowania jest rymowanie przez Jaworskiego samogłosek nosowych i ustnych przy częstym uwzględnieniu w piśmie odnosowienia wygłosowej lub objętej rymem samogłoski: żyzne : zgnilizne, na sie : pasie, Rolę: kqqkole, chwile (lp) : mile, ginie : Pustynię, plemie - ziemię, topieli : napieli. Jak widać, dwojaki jest mechanizm powstawania tego typu rymów: albo współbrzmieniem objęte są formy, z których jedna systemowo nie po- 
siada nosowości, albo formy, którym normatywnie ta denazalizacja przysługuje, lecz jeden z członów pary jest jej pozbawiony. Spod rygoru rymu dokładnego (w warstwie graficznej) teksty Jaworskiego wyłamują się poprzez częste rymowanie ę : en: niepoięta : Talenta, ponętach : Talentach. To w zasadzie jedyne odstępstwa od rymów dokładnych graficznie, jednakże ze względu na fakt, iż notacje z uwzględnieniem odnosowienia wygłosowego e spotykam także i w śródwierszu, i w partiach prozatorskich (np. połkneła), trudno mówić o świadomym operowaniu przez panegirystę tą prawidłowością fonetyczno-ortograficzną. Bez wątpienia stwierdzić należy, że pod tym względem polszczyzna kijowska końca XVII wieku nie odbiegała od normy ogólnej (por. SMolıńsKA, 1983: 24).

Poza miejscami nacechowanymi stylistycznie zaburzenia dotyczą oddawania wtórnej nosowości obu samogłosek, na przykład: iakięś, Twę, swę, mąm, pięnie, burzliwęy, zmyslnę. Prócz tego w Pełni riężyca... odnajduję wiele notacji z - ę w liczbie mnogiej zaimków rodzajowych i rzeczownych, w liczebnikach i rzeczownikach (poza tym $w$ bierniku rodzaju żeńskiego, gdzie systemowo było jeszcze -e)), na przykład: twę, katuszę, ręcę. Pojedyncze podobne przykłady u Jana Władysława Poczobuta i Antoniego Kazimierza Sapiehy odnotowała Barbara SMolińSKA (1983: 25).

W analizowanych tekstach kijowskich zdarzają się również poświadczenia synchronicznej wymowy połączeń samogłoski i spółgłoski nosowej (wtórna nazalizacja antycypacyjna): męczęskich, choć obok męczenik - konsekwentnie i we wszystkich pozycjach zapisywany bez podwojenia $n$. Podobne zapisy $e N>e$ u pisarzy północnokresowych wywołały dyskusję pomiędzy badaczami, którzy skłonni byliby w hiperpoprawności pisowni widzieć ich uzasadnienie (zob. Kurzowa, Trypućko, Zaleski). Innego zdania jest idąca za Kazimierzem Nitschem Smolińska - i ku tej genezie się przychylam:

[...] wielość przykładów, pojawiająca się $w$ bardzo różnych stylistycznie tekstach u tak licznych autorów pochodzenia kresowego, przy braku jednocześnie takich zapisów w innych regionach Polski, świadczyć może jednak o tym, że nie mamy do czynienia jedynie z kwestią pisowni.

SMOLIŃSKA, 1983: 38

Wśród piszących po polsku pisarzy skupionych wokół kijowskiego kolegium zapisy e zamiast en nie są wprawdzie częste, ale jednak zauważalne - poza Jaworskim używają ich także Joannicjusz Galatowski (np. skączenie) i Piotr Mohyła (przeklęstwu).

Często $w$ pracach Jaworskiego występuje także a zamiast $\ell$, np.: zasiaga, Swiątego.

Co do nosówki tylnej - w pozycjach niezależnych spotyka się denazalizację a do o: wcisnot, iakoś (zamiast iakąś). Na szczególną uwagę, jak podkreślała Zofia Kurzowa (2006: 99), zasługują formy z odnosowionym $a \mathrm{w}$ imiesłowach przysłówkowych uprzednich, nieznanym $w$ polszczyźnie ogólnej. Jaworski, podobnie jak inni polskojęzyczni autorzy kijowscy i pochodzący z Kresów północnych (Atanazy Kalnofojski, Galatowski, Mohyła; zob. KLıмeк, 2011), stosuje zapisy typu: przyiowszy, wydźwignowszy, powziowszy, wziowszy, przeniknowszy, wionowszy, wycisnowszy, a obok nich: wybuchnq̨wszy, zakwitnquszy, co pozostaje bez związku z akomodacją stylistyczną. Identyczne formy notują między innymi

${ }^{3}$ Uznaję, że to on jest tłumaczem anonimowo wydanych Listów Swięte ${ }^{o}$ Oyca Partheniusza (1643). 
SMolı́́ska (1983: 40) u Poczobuta i Sapiehy, a także SıcıńsKa (2013: 122) w epistolografii południowokresowej, choć tylko „17 tego typu przykładów u 10 autorów”.

W zakresie grafii (i odzwierciedlającej się poprzez nią fonetyki) uwagę zwracają także dwa typowe dla polszczyzny kijowskiej, a rzadkie już w polszczyźnie ogólnej końca XVII stulecia, zjawiska. Pierwszym jest zaburzenie miękkości spółgłosek (nie tylko $h, r, l$, jak to zwykle bywało) polegające zarówno na naddatku palatalności: lichim, uciechi, Chitrościi, stimuluie, depozitu, dedikować, Panegyriki, Jutrzeńki, pochiby, chiba, experimentẽ, uchibiwszy, Jaśny, rzeć, wiridarzowi, jak i na wprowadzeniu wtórnej niepalatalności: drogy, Olympie, zacmia, zdzbło, niesmiertelności, Panegyry, Panegyriki, Lyry, merziony, Niesmertelne ${ }^{o}$, Pyramidzie, snieżystym - niezależnie od pochodzenia (obcego czy słowiańskiego) wyrazu. Odnośne notacje $w$ panegirykach Jaworskiego nie są motywowane stylistycznie, pojawiają się i $w$ prozie, i $w$ poezji - $w$ tej ostatniej zarówno $w$ rymach, jak i poza nimi. Co więcej, nawet motywacja rymowa nie jest uzasadnieniem dla miękkiej spółgłoski, gdyż współbrzmienia są albo gramatyczne, albo zmiękczenie występuje w obu wersach, na przykład: płochi : lochi. Identyczne mieszanie $i$ oraz y niezależnie od typu tekstu zauważyłam także u innych pisarzy publikujących w oficynie ławry: Mohyły, Łazarza Baranowicza i Filipa Orlika (Кцıмек, 2011, 2013), a przykładów z Kresów południowo-wschodnich dostarczają badania Kurzowej (2006: 62) i SicińsKiej (2013: 91).

Drugim z typowych, jak się wydaje, dla polszczyzny XVII-wiecznego Kijowa zjawisk są zaburzenia w oznaczaniu $\nmid-l$, u Jaworskiego między innymi: Krołewstwu, wywiklane, uwiklać, Kołumnie, wyslawiony. Iryda Grek-PAbisowa i Irena Maryniakowa (1997: 59) podają, że „należy [ono] do rzadko notowanych zarówno w przeszłości, jak i gwarach współczesnych" polszczyzny północnokresowej i przywołują cztery notacje siedemnastowieczne. Tymczasem sięgnięcie do kolejnych źródeł kijowskich dostarcza kilkakrotnie więcej przykładów, a dalsze już na przełomie stuleci odnotowała w pamiętniku Sapiehy Smolı́́sKa (1983: 49). Badaczka sformułowała przy tym tezę, do której i ja się przychylam, że „można z wielką ostrożnością uważać [mieszanie $t-l$ - J.K.-G.] za sprawę wymowy [a nie tylko grafii J.K.-G.] i traktować jako cechę o charakterze lokalnym, spowodowaną z jednej strony względami hiperpoprawnościowymi [...], z drugiej - wpływami ruskimi" (SMolı́́sKA, 1983: 49).

Potwierdzeniem kompetencji językowych Jaworskiego $w$ zakresie morfologii jest swoboda, z jaką czerpie z potencjału tkwiącego we fleksji końca XVII stulecia. Znacznie trudniej jednak wskazać cechy, które można by uznać za specyficznie kijowskie. Możliwe jest jedynie stwierdzenie, w jakiej mierze odległość od centrum przekłada się na zachowywanie form recesywnych czy archaicznych.

W największym stopniu poeta wykorzystuje wariantywność końcówek narzędnika liczby mnogiej rzeczowników wszystkich rodzajów, w rymach (choć nie tylko) korzystając ze starszej końcówki -y(-i), np. maniery : charaktery, tytuły : karbunkuły, żywioły : zioły, rzeczy : mieczy, kolory : flory, pochwały : kanały, nektary : pożary, nauki : sztuki, pęty : Swięty, splendory : kędziory, stopy : pyropy, złoty : wroty, ślady : gady, cugi. Dłuższa o sylabę nowa końcówka -ami występuje z rzadka w partiach wierszowanych: udami, żyłami, ale regularnie za to w prozatorskich: Luminarzami, lampami, głosami, promieniami. Taki rozkład końcówek warunkowany jest jednak typem wypowiedzi, a nie regionalnie, co potwierdzają badania prowadzone przez Smolińską na tekstach pamiętników Sapiehy i Poczobuta, gdzie prym wiedzie - zgodnie z normą potoczną - końcówka -ami (SMolıńsKA, 1983: 77). 
W utworach Jaworskiego wariantywne lub starsze końcówki nader często uzasadnione są poetycko. Dokładność rymu i zgodność sylabiczną wersu poeta osiąga za sprawą:

1) starszego celownika liczby pojedynczej -u: Stworzycielu (: wielu), Krolewicu (: licu); obok końcówka -owi niezależnie od tekstu: Kupcowi (: mowi);

2) mianownika liczby mnogiej rzeczowników męskożywotnych i nijakich -i(y)/-owie: Wieszczkowie (: powie), niebiosy (: losy), Demostheny (: Atheny), Homery, Ulissy, Solony : Platony, Theopompy;

3) dopełniacza liczby pojedynczej miękkotematowych rzeczowników żeńskich: Pustynie (: przypłynie), (płynie :) Monarchinie - ta sama końcówka także w miejscach, gdzie brak uzasadnienia funkcjonalnego, na przykład gubernie, pochodnie, co pozostaje $w$ zgodzie z twierdzeniem Ireny Bajerowej, że -'e zanika od początku XVIII wieku (BAJERowA, 1964: 80).

W tekstach Jaworskiego zdarzają się również końcówki starsze, które nie są warunkowane względami stylistycznymi, na przykład dopełniacz liczby pojedynczej Arabiey, biernik liczby mnogiej z -ów: Indianow, Luminarzow, i z -e: Luminarze. Znacznie łatwiej odnaleźć końcówki nienormatywne usprawiedliwione dokładnością rymu: znamie (D. Ip) (: Barłaamie), (chwili :) krotofili (B. Im), (drugi :) strugi (C. Im), kamienie (D. Im) (: nasienie), Luminarze (B. Im) : parze, Eole (W. Ip) (: niedole), tonie (D. Ip) (: Jazonie), a także w śródwierszu, gdy w grę wchodzi motywacja rytmiczna: $w$ tonią.

Ciekawie przedstawiają się modyfikacje, jakim ze względów rytmicznych (czasami też rymowych) Jaworski poddaje nazwy własne. W zależności od wymogów rytmu skraca lub (rzadziej) wydłuża temat, nawiązując do postaci łacińskich i greckich imion, i tak powstają: mianownik Macedo, dopełniacz Macedona od Macedończyk lub utworzonego wcześniej Macedo, Morfea od Morfeusz, Phaetonta od Phaeton, Thezea : Promethea od Tezeusz i Prometeusz. Tuż obok sytuuje się tworzenie neologizmów, na przykład Lerny 'hydry lernejskie' w rymie do niezmierny.

W zakresie czasownika możliwości akomodacyjne są znacznie mniejsze niż w wypadku rzeczownika, ale i tu Jaworski wykazuje się znajomością wszystkich mechanizmów i skrzętnie wykorzystuje cały potencjał siedemnastowiecznego czasownika, gdy trzeba, sięgając do zasobów polszczyzny kresowej i form archaicznych. Stosuje ruchome końcówki fleksyjne w czasie przeszłym, przyłączając je najczęściej do niesamodzielnych części mowy: gotowem, jużeś, otoś, a także posługuje się starszą, ograniczoną do Kresów (zob. SMolińsKA, 1983: 97-98), końcówką 1. osoby liczby mnogiej -m: niewidzim. Poza tym, chcąc uzyskać rym dokładny, modyfikuje temat fleksyjny czasownika: zakamiało (: miało), utkwiała (: strzała), skamiała (: zdumiała), choć rozszerzenie samogłoski skutkujące zmianą tematu występuje również bez motywacji stylistycznej: widziemy, obaczemy (u Sapiehy m.in. czyniemy, musiemy; zob. SMOLIŃSKA, 1983: 21).

Cechą łączącą Jaworskiego z innymi pisarzami kręgu Akademii Kijowsko-Mohylańskiej jest brak logicznego następstwa czasów w opowiadaniu historycznym. Metropolita chętnie sięga po czas teraźniejszy bądź przyszły zamiast przeszłego - zarówno w partiach wierszowanych:

Slepy mu wzrok otworzył duszewny / a Drugi

Wewnętrzne mu zmył lice iak wodnemi strugi.

Z długiej bowiem rozmowy z ułomnemi / snadnie 
Myśl Duchowna się jemu do serca zakradnie /

Słysząc od Starcow rzeczy przedtym niewiedziane

Pełnia riężyca...,

jak i prozatorskich:

[...] tegoż kamienia Barlaamowe ${ }^{\circ}$ swietny promień, y moiey płochości oświeca caliginem, tak iż wszystko Quidquid sum, possum, habeo wszystko to na stałym onego kamienia ugruntowałem fundamencie

Arctos caeli...

W zakresie składni uwagę zwracają także modyfikacje związków składniowych z czasownikiem, skutkujące zgodnością rymowo-rytmiczną. Akomodacja w tym zakresie obejmuje: 1) zmianę rekcji czasownika: przyćmić + dopełniacz: Coby przyćmic ci miało pogodnego czoła (: zgoła), przycmić Cynozury (: chmury);

2) zmianę składni (z kazualnej na przyimkową lub odwrotnie): podobne Kupcowi (: mowi), podobny żelazu (: Kaukazu), na wstecz niewracały;

3) zmianę składni powiązaną ze zmianą przyimka w konstrukcjach przyimkowych (pod wpływem ruskim): pospieszył $w$ Pyropy, wchodził $w$ pawilony (: strony), w Pustynię by zasłany, idzie $w$ świat, $w$ dalekiey znachodzi Pustyni, uchodza $w$ horyzont, na Pałace chodzit, wspiera się od min;

4) naruszenie składni przy orzeczeniach zaprzeczonych: nie strzymawszy tak wielka machinę (: minę), mało cały Swiat nie wparły na minę.

Warto zwrócić uwagę również na wciąż wariantywną u Jaworskiego postać przedrostka superlatywnego na- i nai-/nay-: namniey, nayniższym, naybogatsze, naystarszy, naybarziey, naiaśnieyszych. Często spotykany jest też superlatywny przedrostek prze-: Przeoswiecony, Prześwietne, nierzadko wzmacniający znaczenie naj-/na-: Przenaydostoyniesza, Przenaswiętsza, Przenaswiętszey. O stopniowaniu przymiotników w analizowanych źródłach warto wspomnieć też $w$ związku z faktem, że Jaworski zmienia konstrukcję stopnia wyższego i jest to postępowanie niemające li tylko motywacji artystycznej. Zamiast typowej dla polszczyzny konstrukcji porównawczej 'stopień wyższy z morfemem -szy + funktor niż' panegirysta sięga po strukturę 'stopień równy + nad': drogi skarb nad Chryzolity (: skryty), obok: droższey nad ktorq, droższy skarb nad złote Tagi (: wagi), stopy co sq iaśniejsze [...] nad pyropy, droższe nad Kolchow Gedeona runo, twardsza nad Marpez ręko.

Zaskakujący jest fakt, iż Jaworski, Rusin z pochodzenia, rzadko wplata do swojej polszczyzny elementy ruskie. Takie cechy odnotować można głównie na poziomie leksyki, na przykład w czasownikach znachodzi, dokupić się, w przysłówkach poczworno, sowito (: Metropolito), daremno, bujno. Obok przysłówków na -o notuje się także te na -e: głupie, mile, pięknie, pogodnie (: pochodnie), wybornie. Uwagę zwracają też przymiotniki i imiesłowy bierne, choć obok form posiadających cechy substratowe można zauważyć formy dowodzące neologicznych ${ }^{4}$ tendencji panegirysty: fabułeczna, łezna, wsidlony, symphoniaczny,

${ }^{4} \mathrm{Na}$ potrzeby rymu dokładnego Jaworski tworzy także neologizmy: fletę (: Waletę), Luminarze (: karze), Lerny (: niezmierny). Konfrontacja materiału wyekscerpowanego z tekstów źródłowych ze Słownikiem języka polskiego Samuela Bogumiła Lindego pozwala także wydzielić grupę złożeń 
stalisty, śnieżysty, zachodowy, widany (: nieoszacowany). Co warto podkreślić, nie mają one zasadniczo wpływu na wartość stylistyczną tekstu.

Analiza polszczyzny dwóch polsko-łacińskich panegiryków Stefana Jaworskiego i konfrontacja danych dotyczących miejsc nienacechowanych i nacechowanych pozwalają stwierdzić, iż poeta niemal w pełni wyzyskuje możliwości tkwiące $w$ wariantywności siedemnastowiecznej polszczyzny ogólnej i jej cechach regionalnych (północnokresowych). Jaworski nie waha się sięgać po cechy specyficzne dla polszczyzny kijowskiej: z jednej strony trochę archaicznej wobec normy ogólnej, z drugiej - zbieżnej z sąsiednimi odmianami kresowymi. Nieco zaskakujące może być jedynie sporadyczne sięganie po cechy ruskie i cerkiewne. W kontekście zwyczajów językowych epoki i środowiska, z którego wyrasta Jaworski, uznać to jednak należy za jedną z cech typowych, unifikujących pisarzy kręgu Akademii Mohylańskiej.

Źródła

JaWORSKI S.: Arctos caeli Rossiaci... Kijów 1690.

Jaworskı S.: Pełnia riężyca $w$ kleynocie swiecqcego... Kijów 1691.

\section{Słowniki}

SL - Linde S.B., 1807-1814: Słownik języka polskiego. T. 1-6. Warszawa.

\section{Literatura}

Bajerowa I., 1964: Kształtowanie się polskiego języka literackiego w XVIII $w$. Wrocław.

Brogi Bercoff G., 2014: Ruś, Ukraina, Ruthenia, Wielkie Księstwo Litewskie, Rzeczypospolita, Moskwa, Rosja, Europa środkowo-wschodnia: o wielowarstwowości i polifunkcjonalizmie kulturowym. W: Alberti A., Garzaniti M., Garzonio S., red.: Contributi italiani al XIII Congresso Internazionale degli Slavisti. Firenze, s. 325-387.

BrüCKNer A., 1918: Wpływy polskie na Litwie i $w$ Słowiańszczyźnie wschodniej. W: Koneczny F., red.: Polska $w$ kulturze powszechnej. Kraków, s. 153-166.

Chronos [online: http://www.hrono.ru/biograf/bio_ya/javorski_s.php; data dostępu: 20.09.2018].

neologicznych Jaworskiego, nienotowanych przez leksykografa: długofortunny, dwoybarczysty, dziękomowna, głosnoryczny, iaśnoświecący, liliorożana, niebopłatna, niebopodobna, ognistosuty, prawdozroczna, strasznokręta, strzałolotne, wdzięcznorożany, wiatrogonne, wierszopłynny, złotołokietna, lub notowanych w zbliżonej postaci: każdodziennie (w SL: każdodzienny), ogniorodna (w SL: ogniorod, ognioroyny), siedmiołebne (w SL: ${ }^{* *}$ siedmiołbista, ${ }^{* *}$ siedmiołbiana, siedmiołbica), wierszopismienna (w SL: wierszopis, wierszopisca, wierszopiska), rymotworska (w SL: rymotworczy, rymotworny). Znacznie mniejszą grupę stanowią złożenia poświadczone w SL: gornolotna, iasnoświetny, kwieciorodna, troyzębny, wysokolotne, złotopłynne, złotopromienna, w tym także opatrzone przez niego kwalifikatorami * 'przestarzałe': *ciemnofałeczna, *swiatłorodny, lub ** 'poetyckie': **bystropłynne. 
Grek-Pabisowa I., Maryniakowa I., 1997: Język polski na Kresach północno-wschodnich dawniej i dziś. W: GreK-PABisowa I., red.: Historia i współczesność języka polskiego na Kresach wschodnich. Warszawa, s. 27-109.

Gulewicz W. (Гулевич В.) [online]: Стефан Яворский - западнорусский камень русского православия [online: http://interaffairs.ru/read.php?item=10453; data dostępu: 20.09.2018].

KLIMEK J., 2010: Status polszczyzny kijowskiej w świetle granic i zasięgu polszczyzny kresowej. W: Kuźmickı M., Osıewicz M., red.: Żywe problemy historii języka. Poznań, s. 179-191.

KlımeK J., 2011: Polonika kijowskie - nierozpoznana odmiana polszczyzny XVII stulecia? Rekonesans. W: Dunaj B., RАк M., red.: Badania historycznojęzykowe. Stan, metodologia, perspektywy. Kraków, s. 91-101.

KLımek J., 2013: Z fonetyki „Listów Swięte Oyca Partheniusza” (1643). „Acta Baltico-Slavica” XXXVII, S. $575-584$.

Kurzowa Z., 2006: Język polski Wileńszczyzny i Kresów północno-wschodnich XVI-XX w. Kraków. Ortho-rus [http://www.ortho-rus.ru/cgi-bin/ps_file.cgi?2_4433; data dostępu: 30.04.2015].

Pinan-Kıjasowa A., 1999: Literacka polszczyzna Kresów północno-wschodnich XVII wieku. Fonetyka. Poznań.

SıCıŃSKA K., 2013: Polszczyzna południowokresowa XVII i XVIII wieku (na podstawie epistolografii). Łódź.

SMolińsKA B., 1983: Polszczyzna północnokresowa z przełomu XVII i XVIII $w$. Wrocław.

William Shakespeare [http://william-shakespeare.gq/Stefan_Yauorsky; data dostępu: 30.04.2015].

Jolanta Klimek-Grądzka

$17^{\text {th }}$-century Kiyuan Polish in Stefan Jaworski's Panegyrics

Sum mary

The article discusses a regional variety of Polish spoken in Kiyu preserved in the Polish-Latin panegyrics composed by Stefan Jaworski (1656(8)-1722) to venerate Warłam Jasiński. The analysis aims at drawing a catalogue of phonetic, inflectional, word formation and syntactic idiolectal features of this variety as jurtaposed against the $17^{\text {th }}$ century standard Polish. The analysis reveals the poet's fluency in a language that was foreign (second) to him. This fluency also covers the poet's skill in using varietal forms to achieve artistic aims. The regional forms subject to the study often display closeness to the ones in the Borderland variety of Polish, yet with an idiolectal inflectional features, e.g.: a large number of participles ending in -owszy or frequent cases of $1 / \nmid$ alternation. 